УДК 78.071.2(477) “ХХ”

DOI:

Ірина Гринчук, кандидат педагогічних наук, доцент кафедри музикознавства та методики музичного мистеитва факультету мистеитв

Тернопільського національного педагогічного університету імені В. Гнатюка Тетяна Грищенко, кандидат педагогічних наук, доцент кафедри музики і хореографії Донбаського державного педагогічного університету

\title{
ФОРТЕПІАННІ ТВОРИ Ф. ЯКИМЕНКА: ІСТОРИКО-МУЗИКОЗНАВЧИЙ ТА ВИКОНАВСЬКО-ПЕДАГОГІЧНИЙ АСПЕКТИ
}

Заторкнуто проблему оновлення навчального і виконавського репертуару у класі фортепіано. Увагу зосереджено на аналізі фортепіанних творів українських композиторів ХХ століття на прикладі творчості Ф. Якименка. Розглянуто культурологічний, музикознавчий контексти, чинники, які вплинули на формування Ф. Якименка як композитора і виконавия. Проведено загальний огляд фортепіанної спадщини композитора у сукупності ї̈ теоретичних і методичних аспектів. Представлено мініатюри з циклу “Три п'єси на українські теми" як приклад иінного навчально-виконавського репертуару.

Ключові слова: фортепіанна творчість украӥнських композиторів І половини ХХ ст.; композиторський стиль; Ф. Якименко; фортепіанний циикл; виконавсько-педагогічний аспект.

Jim. 11.

Iryna Hrynchuk, Ph. D.(Pedagogy), Associate Professor of the Musicology and Methods of Music Art Department, Ternopil Volodymyr Hnatyuk National Pedagogical University

Tetyana Hryshchenko, Ph.D.(Pedagogy), Associate Professor of the Music and Choreography Department, Donbass State Pedagogical University

\section{PIANO WORKS BY F. YAKYMENKO: THE HISTORICALAND MUSIC, PERFORMANCE AND PEDAGOGICALASPECTS}

The instrumental training, piano training in particular, is an important component in the professional preparation of the musicians and music teachers. In its theoretical and methodological background, there must be combined the historical, theoretical, musicological, pedagogical, performance, analytical and interpretive aspects.

The article highlights the study of the national piano repertoire in the context of the development of European and world music culture with the purpose of its extrapolation for the tasks of general and special pedagogical practice. An appropriate repertoire textbooks in different editions serve as a methodological background in this context.

In its performance, pedagogical and repertoire aspects, piano art of Ukraine is closely linked with the European musical context during the interwar period of the twentieth century. It had been facilitated by Ukrainian artists being trained by the leading music teachers of European capitals; their multifaceted concert tours and pedagogical activities both in Ukraine and in Europe; direct creative activity of representatives of the Ukrainian diaspora.

F. Yakymenko, a composer, pianist and teacher, music critic and music theorist, author of a valuable piano repertoire is a vivid example of the generation of Ukrainian musicians of the above mentioned time.

There has been outlined the place of F. Yakymenko as the author of some samples of national piano creativity against the background of the European cultural context.

There have been analyzed the peculiarities of F. Yakymenko's piano writing in historical, musical, performance and methodical aspects as the illustrateion of program miniatures of the Prague period of his creative activity.

Being a representative of neo-romanticism, a specific feature of F. Yakymenko's creative activity is "stratification" of various historical-stylistic and genre-intonational features. The range of themes of the composer's works embrace the various directions: pictorial and spiritual works; works close to the "synthesis of arts"; music close to compositions by K. Debussy and M. Ravel; the children's music.

There has been analysed F. Yakymenko's creativity during the Prague period, a vivid example of which is the cycle "Three plays on Ukrainian themes".

There has been concluded that F. Yakymenko's versatile program miniatures can be successfully used as educational repertoire material in the process of professional piano training, as an illustrative repertoire material in the process of organizing listening to music by schoolchildren.

Keywords: piano works by Ukrainian composers of the XX century; the composer's style; F. Yakymenko; piano cycle; performing and pedagogical aspect.

П

остановка проблеми й аналіз останніх досліджень. Фахова фортепіанна підготовка майбугнього музиканта-педагога - цілісний феномен, що поєднує історико-теоретичний, музикознавчопедагогічний, виконавсько-методичний, аналітико- 
інтерпретаційний аспекти. У цьому контексті актуальною залишається проблематика дослідження українського фортепіанного репертуару як виконавського, художньопедагогічного та дидактичного матеріалу, що забезпечить студентові основу для осмислення цілісної картини становлення національного фортепіанного репертуару у контексті розвитку європейської та світової музичної культури для наступної екстраполяції на завдання загальної і спеціальної педагогічної практики.

Музикознавчим підгрунтям виступають узагальнюючі дослідження з історії становлення українського фортепіанного репертуару М. Дремлюги, В. Клина [2], Н. Кашкадамової [1], О. Козаренка, О. Лігус [9], О. Олійник, Н. Ревенко, Л. Свірідовської, О. Фрайт та ін. Музикознавчометодичний пласт фортепіанної літератури українських композиторів різних епох представили укладачі репертуарних хрестоматій М. Степаненко, T. Завадська і О. Козачук [8], У. Молчко, О. Німилович, О. Рапіта, Л. Філоненко, І. Гринчук і О. Горбач [10] та інші піаністи-дослідники і педагоги.

Однак, актуальним завданням є упорядкування і вивчення українських фортепіанної спадщини композиторів минулого століття, представників української діаспори, зокрема і Ф. Якименка [5], повернення їх кращих фортепіанних зразків до сучасної концертної і навчальної практики.

Мета статті - спроба окреслити місце Ф. Якименка як автора зразків національної фортепіанної творчості на тлі європейського культурного контексту. Завдання статті проаналізувати особливості фортепіанного письма $Ф$. Якименка в історико-музикознавчому та виконавсько-методичному аспектах на прикладі зразків програмних мініатюр празького періоду його творчості.

Виклад основного матеріалу. Фортепіанне мистецтво України міжвоєнного періоду ХХ ст. у його виконавському, педагогічному, репертуарному аспектах тісно пов'язане із загальноєвропейським музичним контекстом тієї епохи. Серед чинників цього “інтеграційного" феномена назвемо наступні: органічне сприйняття, переосмислення та “жанрову асиміляцію” (О. Лігус) [9] традиційних і новітніх стильових тенденцій тогочасного європейського фортепіанного мистецтва, зокрема, через навчання українських митців у провідних зарубіжних композиторів та педагогів європейських столиць; багатогранна концертно-гастрольна діяльність українських виконавців як в Україні, так і в Європі; безпосередня творча діяльність представників плеяди українських митців, композиторів та педагогів, які в силу суспільно-історичних обставин змушені були емігрувати, творячи українське фортепіанне мистецтво поза материзною, “безпосередньо вписуючи” його таким чином у загальноєвропейський контекст.

Прикладом такого феномена служить творча спадщина Ф. Якименка [5], для якої характерним стало “нашарування" різних історико-стильових та жанрово-інтонаційних ознак у становленні стилістики письма на різних етапах творчості (Л. Корній [3], Н. Кашкадамова [1], І. Новосядла [6] та ін.).

Внаслідок вимушеної еміграції, творча спадщина Ф. Якименка (1876 - 1945), старшого брата Якова Степового (Я. Якименка), чий творчий доробок більш знаний в Україні [5; 7], була тривалий час вилучена 3 контексту національного мистецько-духовного життя, і лише від часу державної незалежності повертається у культурно-мистецький та освітній простір.

Сучасні музикознавці характеризують Ф. Якименка як видатного композитора, успішного піаніста і педагога, музичного критика та теоретика музики, автора першого україномовного підручника 3 гармонії, автора цінного фортепіанного репертуару. Однак, упродовж тривалого часу Ф. Якименка трактували як російського композитора (“Енциклопедія музики і музикантів Макміллана”, "Бібліографічний словник музикантів Бейкера" (Нью-Йорк), “Словник музики Гроу”, дослідження російських музикознавців К. Матюшиної, Л. Корабельнікової та ін.) (за І. Новосядлою) $[6,112]$.

Про Ф. Якименка як українського митця першим писав П. Маценко [4], підкреслюючи його українське походження, національну самобутність творчості, посилаючись на спогади дослідників і сучасників. Цінні спогади про Ф. Якименкапедагога залишили М. Колесса, 3. Лисько [5; 7]. I. Новосядла узагальнює: "Українець за своєю суттю і походженням, тісно пов'язаний із російською національною музичною школою, митець черпав свіжі ідеї в європейській культурі, при цьому створивши свій внутрішній світ, який він “вилив” у музичних звуках” [6, 123].

Так, узагальнюючи палітру та рівні культурних впливів, які визначили характерні прикмети індивідуального композиторського стилю Ф. Якименка як представника харківської фортепіанної школи, Н. Кашкадамова [1] пише про роль чеських педагогів, “двосторонніх зв'язків 3 берлінським музичним середовищем”, про “Лістівсько-Чернівську традицію великого віртуозного романтичного виконавства”, про роль 

ПЕДАГОГІЧНИЙ АСПЕКТИ

російської романтичної віртуозної традиції від братів Рубінштейнів, С. Рахманінова, який від дитинства мав тісні зв' язки із Слобожанщиною, з родинами Слатіних, Лисикових, українських просвітників і меценатів Алчевських, понад 13 разів приїздив із сольними програмами $[1,57$ 59]. Зразки зрілої творчості Ф. Якименка демонструють поєднання здобутків німецького романтизму, бузонівського неокласицизму 3 мелосом української народної пісні, синтез елементів романтизму з елементами французької імпресіоністичної музики та ін.

Значний вплив на формування стилістики його композиторського письма мали період навчання у Придворній співацькій капелі, у Петербурзькій консерваторії (класи композиції, фортепіано, органу, скрипки, гармонії), творче спілкування із О. Скрябіним уЖеневі, із французьким музичним критиком М. Кальвокорессі та ін. Підгрунтям композиторського письма став і власний фортепіанний педагогічний досвід, який Ф. Якименко набував у Тифлісі (1901 - 1903), у Ніцці (1903 - 1906), у Харківському інституті шляхетних дівчат та музичному училищі IPMT (1906 - 1911), у Санкт-Петербурзькій (Петроградській) консерваторії (1915 - 1923), де був першим викладачем 3 гармонії у I. Стравинського, педагогічний досвід у період еміграції у Празі і Парижі [5, 340 - 341].

Своєрідну апробацію його фортепіанні твори проходили впродовж концертів в Україні, зокрема, в Києві, Харкові, де крім авторського виконання звучали в інтерпретації О. Горовиця, дядька В. Горовиця $[1,16]$, Р. Геніки, та гастролей у Франції та Швейцарії, у Німеччині (1926).

31923 р. Ф. Якименко змушений був емігрувати, жив у Парижі, згодом - у Празі, де впродовж 1923 - 1924 рр. займав посаду професора, декана музично-педагогічного факультету Українського Вищого Педагогічного Інституту імені М. Драгоманова, вів концертнопіаністичну та диригентську діяльність. Саме у цей період, як зазначає Н. Кашкадамова, він найбільше звертався до української музики, часто використовував український мелос у своїх творах $[1,61]$. Слід підкреслити, що у міжвоєнний період Прага як “перехрестя” західноєвропейських культур стала важливим центром суспільнополітичної, культурно-просвітницької діяльності української еміграції, “інтелектуальним і творчим підгрунтям” для кристалізації національної ідеї, де творила плеяда українських музикантів (В. Барвінський, М. Колесса та ін.) [5], поетів та літераторів (О. Олесь, Є. Маланюк, О. Теліга, Ф. Стешко та ін.).
Після переїзду у 1927 р. до Франції, митця було запрошено до Парижу на посаду професора по класу фортепіано до Нормальної Російської консерваторії, а з 1932 року - як віце-директора цього учбового закладу. Помер Ф. Якименко 3.01.1945 р. у Парижі, де і похований [5; 6].

Підкреслимо, що Ф. Якименко плідно працював у сфері створення українського фортепіанно-педагогічного репертуару, збагатив його жанрову та стильову сфери. Так, Н. Кашкадамова, посилаючись на автобіографію композитора, пише, що перші фортепіанні твори були видані вже у 1900-х рр., а до 1911 р. було створено уже понад 100 опусів. Загалом, фортепіанна спадщина композитора представляє зразки різних жанрів: сонати, сонати-фантазії, “Українська сюїта", прелюди, прелюдії, ескізи, балади, “Ідилічні танці”, кілька зошитів програмних п’єс.

Помітне місце у фортепіанній творчості Ф. Якименка раннього періоду займає жанр етюду та прелюдії (згруповані у декілька циклів з великою кількістю номерів, вони, на думку В. Клина [2], були нетиповим зразком для української фортепіанної музики того часу). Як пише О. Козачук, “Десять прелюдій” ор. 46 демонструють стилістику раннього періоду, який “характеризується досконалим володінням формою, схильністю до хроматизмів, змін ритмічного малюнку" $[8,5]$.

У доробкумитця $є$ програмні твори великої та розгорнутої форми, зокрема, “Фантастична соната", поема "Уранія”, присвячена К. Фламмаріону, “Фантастичне скерцо”, “Фантазія”; фортепіанні ансамблі з програмними назвами, створені під впливом закордонних подорожей: “Весною в Альпах”, “Руїни Римського форума”, “В Люксембурзькому саду”, “Під склепіннями собору Паризької Богоматері” ор. 41 та інші твори.

Загалом, для творчості Ф. Якименка характерні досконале володіння формою і знання композиторської техніки, витончений смак, “елегантність” і багата поетична “настроєність”, насиченість колористичними та стилістичними знахідками. Так, його програмні зразки “Фантазія" (ор. 26), “Примхи моря” та "Мрії на березі моря" (ор. 27), цикл “Розповідь мрійливої душі” (ор. 39), “Багатель” (ор. 48 № 1), “Мелодія” (ор. 48 № 2), “Весняні мрії” (ор. 48 № 3) - яскраві приклади багатогранної фортепіанної стилістики композитора, сповнені настрою, мальовничості та фантазії, які майстерно втілюють миттєві художні враження композитора (О. Козачук) [8, 4 - 5].

Домінуючим $\epsilon$ твердження, що музика 
композитора репрезентує ознаки романтичного (неоромантичного) напрямку, містить елементи “українського імпресіонізму” з характерними рисами гармонічної тональної “амбівалентності” як у творах М. Леонтовича (І. Савченко). О. Фрайт [11] зазначає про символістські тенденції української фортепіанної музики початку XX ст., співставляючи зразки творчості Ф. Якименка та Б. Лятошинського ("Відображення"), із стилістикою Л. Ревуцького, В. Косенка, С. Людкевича, В. Барвінського, 3. Лиська, Н. Нижанківського [5] та ін., які перосмислювали модерні стильові ознаки на грунті національної традиції, народного мелосу.

Н. Кашкадамова характеризує фортепіанні твори зрілого періоду як приклади стилістики “сецесії, де прикмети символізму, риси імпресіонізму, романтичної традиції поєднані із “неокласичним намаганням відродити музичну манеру старовини" $[1,62]$. Власне для сецесії притаманна ідея синтезу мистецтв, злиття музики і філософії, науки, до яких Ф. Якименко звертався не лише у творах, але й публікаціях (“Ліст і Данте”, “Слово і музика”, “Сфера музики”, “Мистецтво у світотворенні”, “Життя у Мистецтві” та ін. (за І. Новосядлою) $[6,117]$.

Ф. Якименко часто звертався до програмної мініатюри, як окремої, так і поєднаної у понад 20 програмних циклів і збірок, які можна структурувати відповідно до певних напрямків: картинно-настроєвого (картинно-пейзажного), вияв синтезу мистецтв, близькість до таємничих, містичних заголовків композицій К. Дебюссі та М. Равеля, дитяча тематика.

До першого напрямку музикознавці відносять цикл “Зоряні мріі”, твори “У вечірню сутінь”, “На свіжому повітрі”, “Весною в Альпах”, “Садок спить”, до другого і третього - згадувані вище цикли “Сторінки фантастичної поезії, "Розповідь мрійливої душі”, “Фантастичну сонату” та ін. До зразків дитячої тематики відносять цикли “Дитячий альбом”, “Ігри” ор. 34, “П’ять прелюдій” ор. 23 з програмними мініатюрами “Фантастична казка”, “Колискова”, “Сон дитини”, “Сон матері”, "Пробудження” та ін.

Від періоду еміграції (від 1924 р.), Ф. Якименко писав твори, у яких втілена ностальгія за втраченою Батьківщиною. Серед них: “Три п’єси на українські теми”, “Шість українських поем”, “Картини України" (“Tableaux ukrainians”), “Українська сюїта" та ін., у яких прослідковується національний інтонаційний комплекс з опорою на обрядовий фольклор та деякі характерні звороти хорової церковної музики.

Розглянемо навчально-методичні аспекти на прикладі програмних п’єс, що входять до циклу “Три п’єси на українські теми”. Зазначимо, що при їх вивченні слід зосередити увагу на особливостях використання елементів фольклорних жанрів, стилістиці та семантиці письма композитора [10].

“Чуттева ідилія” - твір тричастинної побудови. Тужливий характер, використання інтонацій української народної історичної пісні “Козака несуть" наближає мініатюру до зразків думного епосу. У подальшому розвитку (Piú mosso) мелодія трансформується: змінюється розмір, збагачується фактура і динамічний план, супровід нагадує бандурні арпеджовані перебори, 3'являються елементи речитативності. Усе в комплексі вибудовує яскраву кульмінацію твору. Реприза динамічна, що повторює початковий музичний матеріал у фактурно-ускладненому варіанті із використанням октавно-акордової техніки, арпеджіато, мелодія збагачена елементами підголосковості.

Фактура п’єси ставить перед виконавцем низку завдань, пов'язаних з “поліфонізацією” викладу, поліметрією, культурою октавно-акордової техніки, педалізації, відповідно до фактурних і гармонічних змін. Отже, твір розрахований на виконавців, котрі володіють належним рівнем піанізму.

“Біля колиск” - п’єса побудована на інтонаціях української народної колискової пісні “Котику сіренький”. Мініатюрі притаманні елементи варіаційності, яка проявляється у фактурних змінах. Мелодія п'єси, відповідно до жанрової програми, спокійна, монотоннозаколисуюча, 3 незначними динамічними нюансами.

Піаністичні проблеми пов'язані 3 “оркеструванням” фактури. Так, мелодія, викладена у “віолончельному регістрі” у партії лівої руки, епізодами звучить на фоні октавних стрибків, рухливих пасажів, арпеджіато, що вимагає гнучкого фразування, наспівного legato, глибокого туше, культури педалізації, відповідно, - пластичності піаністичного апарату. Переважаюча динаміка гучності $p, p p$ передбачає використання лівої педалі як механізму зміни тембральності звучання.

“Святкова”-твір написаний натемуукраїнського народного танцю гопака. Пісенні та інструментальні супроводи гопака, як правило, яскравого, піднесеного, величного, героїчного характеру з елементами жартівливої гри-дійства. Означений вище характер “Святкової” виражений, зокрема, акцентами, $s f$, стрибками на широкі інтервали в партії лівої руки, динамікою гучності $f, f f$, октавно-акордовою фактурою, яка поступово ускладнюється. 
Можемо узагальнити, що проаналізовані мініатюри циклу“Три п’єси на українські теми”яскраві приклади органічного поєднання національного мелосу із стилістичними пошуками тогочасної епохи, одночасно - зразки індивідуального композиторського письма Ф. Якименка. Так, фактура творів “частіше прозора, економна, навіть графічна. Ї̈ характеризує позиційний виклад без романтичної масивності” (Н. Кашкадамова) [1, 62]. Разом 3 тим охоплюється і наповнюється колористикою уся фортепіанна звучність завдяки гармонічному багатству, де “пряні септ- i нонакорди, цілотоновість, біфункційні поєдання співставляються 3 діатонікою й плагальністю" [1, 62], завдяки педальній різноманітності і насиченості.

Як зазначав Ф. Якименко у І виданні 2-томного фортепіанного випуску: “...автор вважає за необхідне попередити пп. артистів-виконавців, що ці твори потребують надзвичайно тонкого нюансування - шляхетності, смаку, а також можливої гармонії душі автора та виконавця. Подібне сполучення сприятиме найбільш точному відтворенню мрійливо-примхливих настроїв композитора" (за Н. Кашкадамовою) [1, 63].

Підсумовуючи огляд фортепіанної спадщини митця в історико-музикознавчомута виконавськометодичному аспектах, зазначимо, що художні вартості фортепіанних опусів Ф. Якименка репрезентували, крім авторського виконання, згадуваних вище О. Горовиця і Р. Геніки, також О. Розанова-Нечаєва, С. Полоцька-Смцова, С. Тарновський, Н. Лаврівська-Біленька. Їх включали до своїх концертних програм піаністи України і діаспори, серед них - В. Винницький, М. Цісик, Ю. Осінчук, Л. Жук, дует у складі Любові та Іринея Жуків та ін. (за Н. Кашкадамовою). До повернення імені Ф. Якименка долучилися народні артисти України I. Блажков та Є. Басалаєва, дослідники О. Ващук i Н. Набокова, піаніст П. Лисий (концерт з нагоди 140-річчя Ф. Якименка уНМАУ ім. П. Чайковського, 2016 p.).

Твори Ф. Якименка видавалася за життя у видавництвах Лейпцига, Праги, Петербурга, Москви, Києва $[1,61]$. Його мініатюри входили до збірок серії "Український Педагогічний Репертуар" (упорядники Г. Беклемішев, В. Золотарьов, Л. Ревуцький, Г. Курковський, В. Косенко, представлені i у сучасних хрестоматійних збірниках української фортепіанної музики [8; 10].

Наведений вище історико-культурологічний та музикознавчий контекст, представлений фортепіанний репертуар є методичною основою для популяризації творів Ф. Якименка у сучасній виконавській концертній та навчальній практиці, адже, як резюмує Н. Кашкадамова, “Якименкокомпозитор та Якименко-виконавець напрочуд добре поєднувалися в одній особі - по-своєму унікальній” $[1,63]$.

Висновки. Вважаємо, що різножанрові програмні фортепіанні твори Ф. Якименка можугь бути 3 успіхом використані як репертуарний матеріал у процесі фахового навчання, як ілюстративний матеріал - у процесі організації слухання музики школярами, оскільки розширюють стильово-жанрову компетентність, сприяють накопиченню слухового досвіду, розвитку аналітико-інтерпретаційних умінь, вдосконаленню музичного смаку і музичної культури молоді загалом.

\section{ЛIТЕРАТУРА}

1. Кашкадамова Н. Б. Фортеп'янно-виконавське мистецтво України. Історичні нариси. Львів, 2017. 616 с.

2. Клин В. Українська радянська фортепіанна музика. Київ: Наукова думка, 1980. 314 с.

3. Корній Л.П., Сюта Б.О. Українська музична культура. Погляд крізь віки. Київ: Муз. Україна, 2014. $592 \mathrm{c}$.

4. Маценко П. Якименко Федір Степанович. Вінніпег 1954.

5. Муха А. Композитори України та української діаспори. Київ, 2004. 352 с.

6. Новосядла I. Федір Якименко: портрет митця у дзеркалі епохи. Музична україністика: європейський контекст. ред.-упор. Л. Опарик. Івано-Франківськ: Супрун В. П., 2015. С. 112-123.

7. Рудницький А. Про музику і музик. Нью-Йорк Париж-Сідней - Торонто, 1980.

8. Українська фортепіанна музика. Педагогічний репертуар для дітей та юнацтва. Частина III. упорядники Т. Завадська, О. Козачук. Київ: Музична Україна, 2010. $184 \mathrm{c.}$

9. Українська фортепіанна музика XIX - початку XX ст. у контексті європейського романтизму (жанрово-стильова динаміка). Київ: Видавництво Ліра, 2017.224 c.

10. Фортепіанні твори українських композиторів: навчальний посібник. Випуск 5. упоряд. : І. Гринчук, О. Горбач. Тернопіль: Астон, 2017. - 96 с.

11. Фрайт О. В. Особливості втілення принципу програмності в українській фортепіанній музиці автореф. дис. на здобуття наук. ступеня канд. мистецтвознавства. Київ, 2000. 18 с

\section{REFERENCES}

1. Kashkadamova, N. B. (2017). Fortepiannovykonavske mystetstvo Ukrainy. Istorychni narysy [Fortepian-performing arts of Ukraine. Historical Essays]. Lviv, 616 p. [in Ukrainian].

2. Klyn, V. (1980). Ukrainska radianska fortepianna 
muzyka [Ukrainian Soviet piano music]. Kyiv, 314 p. [in Ukrainian].

3. Kornii, L.P. \& Siuta, B.O. (2014). Ukrainska muzychna kultura. Pohliad kriz viky [Ukrainian music culture. A look through the ages]. Kyiv: Muzychna Ukraina, 592 p. [in Ukrainian].

4. Matsenko, P. (1954). Yakymenko Fedir Stepanovych [Yakimenko Fedir Stepanovich]. Vinnipeg.

5. Mukha, A. (2004). Kompozytory Ukrainy ta ukrainskoi diaspory [Composers of Ukraine and the Ukrainian Diaspora]. Kyiv, 352 p. [in Ukrainian].

6. Novosiadla, I. (2015). Fedir Yakymenko: portret myttsia u dzerkali epokhy [Fedir Yakimenko: portrait of the artist in the mirror of the era]. Musical Ukrainian Studies: European Contex. (Ed.). L. Oparyk. IvanoFrankivsk: Suprun V. P., pp. 112-123. [in Ukrainian].

7. Rudnytskyi, A. (1980). Pro muzyku i muzyk [About music and musicians]. Niu-York - Paryzh - Sidnei Toronto. [in Ukrainian].
8. Ukrainska fortepianna muzyka. Pedahohichnyi repertuar dlia ditei ta yunatstva (2010). Chastyna III. [Ukrainian piano music. Pedagogical repertoire for children and youth. Part III]. (Ed.). O. Kozachuk. Kyiv: Muzychna Ukraina, 184 p. [in Ukrainian].

9. Ukrainska fortepianna muzyka XIX - pochatku XX st. $\mathrm{u}$ konteksti yevropeiskoho romantyzmu (zhanrovo-stylova dynamika) (2017). [Ukrainian piano music of the 19th and early 20th centuries in the context of European romanticism (genre-style dynamics)]. Kyiv: Lira, 224 p. [in Ukrainian].

10. Fortepianni tvory ukrainskykh kompozytoriv: navchalnyi posibnyk (2017). [Piano works of Ukrainian composers: tutorial. Issue 5]. (Ed.). I. Hrynchuk, O. Horbach. Ternopil: Aston, 96 p. [in Ukrainian].

11. Frait, O. V. (2000). Osoblyvosti vtilennia pryntsypu prohramnosti $\mathrm{v}$ ukrainskii fortepiannii muzytsi [Features of the implementation of the principle of programming in Ukrainian piano music]. Extended abstract of candidate's thesis. Kyiv, 18 p. [in Ukrainian].

Стаття надійшла до редакції 06.02.2019

УДК 37.015 .3

DOI:

Світлана Ісаєва, кандидат педагогічних наук, доиент кафедри іноземних мов математичних факультетів Київського національного університету імені Тараса Шевченка

\section{ДВАНАДЦЯТЬ ТИПІВ РЕАКЦІЙ ЯК ПЕРЕШКОДИ НА ШЛЯХУ ЕФЕКТИВНОЇ ПЕДАГОГІЧНОЇ КОМУНІКАЦЇ̈}

У статті наголошується на необхідності вивчення світового педагогічного досвіду з метою удосконалення теорії і практики навчально-виховного процесу. Підкреслюється надзвичайна актуальність проблеми ефективної педагогічної комунікації. Згадуються відомі давні мислителі, які вдавалися до комунікаиії в різні часи, та сучасні вітчизняні й зарубіжні науковці, які досліджують дане питання. Особлива увага приділяється науковій спадщині американського психолога і педагога Томаса Гордона. Проаналізовано виокремлені вченим дванадиять типів реакцій, щчо заважають ефективній педагогічній комунікації між вчителем і учнями. nростір.

Ключові слова: педагогічна комунікація; Томас Гордон; реакиія; перешкоди; спілкування; освітній

Jim. 14.

Svitlana Isayeva, Ph. D.(Pedagogy), Associate Professor of the Foreign Languages for Mathematical Faculties Department Taras Shevchenko National University of Kyiv

\section{TWENTY TYPES OF REACTIONSAS OBSTACLES TO EFFECTIVE PEDAGOGICAL COMMUNICATION}

The article emphasizes the necessity of studying the world pedagogical experience in order to improve the theory and practice of the educational process. The urgency of the problem of effective pedagogical communication is accentuated. Famous ancient thinkers, who resorted to communication at different times, and modern domestic and foreign scholars, who are investigating this issue, are mentioned. The analysis of scientific, psychological and pedagogical literature has been carried out. It is stressed that the need to overcome the "crisis of communication" and the necessity to renew the system of upbringing and education have become especially relevant in connection with the entry of Ukrainian young specialists into partnership business contacts with European experts and partners. The importance of enriching the domestic pedagogy with the achievements of foreign scholars because of the processes of globalization of educational space and the interpenetration of pedagogical ideas from different cultures is underlined. Particular attention is paid to the scientific heritage of American psychologist and educator Thomas Gordon. Twelve types of reactions, distinguished by the scientist, which interfere with effective pedagogical communication between a teacher and students, namely: an order; warning, threat; notations, teachings; advice or 